\title{
Banking Financial Services Risk Based on Information Management System
}

\author{
Ming Lu \\ ZhongGang DaGong Technology, Beijing, China \\ 30256663@qq.com
}

Keywords: Financial product innovation; risk; commercial banks.

\begin{abstract}
To explore the risk of banking financial services under the background of information management, the connotation of financial product innovation in commercial banks is studied, and the motivation of financial product innovation is analysed. In addition, a new repeated game model of financial product innovation with spill-over effects and different competitive strategies and risk constraints is set up. The Nash equilibrium point of the model was determined and the stability conditions of the equilibrium point are discussed. The risks faced by the innovation of financial products are analysed. On the basis of the analysis of the characteristics of the innovation risk of financial products, the risk transmission mechanism of the innovation chain of financial products is discussed. The new model of internal risk management and external risk supervision of Chinese commercial banks' financial products innovation is made, and the corresponding countermeasures and suggestions on how to improve the risk management level of commercial banks' product innovation are put forward.
\end{abstract}

\section{Introduction}

Finance is the core of modern economy. In the current world economic structure, the financial industry has shown a strong support and driving effect on the development of regional economy. It has gradually become the leading industry of modern economy, and continues to promote the development of the economy. All the countries of the world have always attached great importance to the development of the financial industry (including banking) [1]. In order to improve their competitiveness, commercial banks have carried out various financial innovation activities according to their own advantages and characteristics. Financial innovation, especially financial product innovation, can increase the income of intermediate business, alleviate the mismatch of time limit, increase the capital adequacy ratio, enhance the market constraints of commercial banks, and promote interest rate marketization and exchange rate marketization, so as to diversify financial risks and improve the risk management ability, transformation and upgrading of commercial banks [2].

However, the innovation of financial products has the function of "double-edged sword". Financial product innovation not only plays a role in dispersing financial risks, but also leads to the emergence and diffusion of new financial risks. The financial crisis triggered by the subprime mortgage crisis in the United States reveals the financial risks arising from over innovation of financial products [3]. A series of events, such as the bankruptcy of mortgage guarantee loan institutions, the bankruptcy of investment banks and the sharp shock of the stock market caused by the American subprime mortgage crisis, have not only made the developed countries in the dominant position in the world financial industry into trouble, but also made the developing countries with relatively backward financial products market aware of the huge risk behind the virtual economy. The global financial crisis caused by the American subprime crisis reveals the profound influence of financial risk on the national economy in the process of producing, accumulating, interacting, contagious and releasing. Therefore, it has become an essential link in the innovation process of financial products for commercial banks to strengthen the identification of the risk of innovation of financial products, and establish an effective risk management model and risk prevention system. 


\section{Research Background}

The debate on the connotation of risk innovation in financial products has never stopped. The current mainstream economists' explanation is that the innovation risk of financial products refers to the uncertainty and interaction of various factors in the macro-economic environment and the financial market under certain conditions [4]. As a result, it makes the actual results of the innovation activities of financial products deviate from the expectations and lead to the possibility of economic loss for various financial behaviour subjects [5]. The innovation of financial products, especially the more and more complex financial derivatives, makes the connection between financial assets and physical assets looser, and the hidden financial risks are more difficult to identify and prevent.

\section{Methodology}

On the basis of extensive consulting the relevant literature at home and abroad, through tracking the research progress of domestic and foreign scholars on financial innovation and risk management, a certain number of previous research achievements have been accumulated [6]. The main contents of this paper are as follows: on the basis of the theory of financial innovation and the theory of mixed dynamics and game theory, the motivation and game behaviour analysis of financial product innovation are discussed. Reliability test and confirmatory factor analysis are used to test the reliability and validity of the scale, and the structural equation model analysis method is used to analyse the path of the key influencing factors of the risk management of financial product innovation in commercial banks. The theoretical models for the risk management of financial products of commercial banks are as follows:

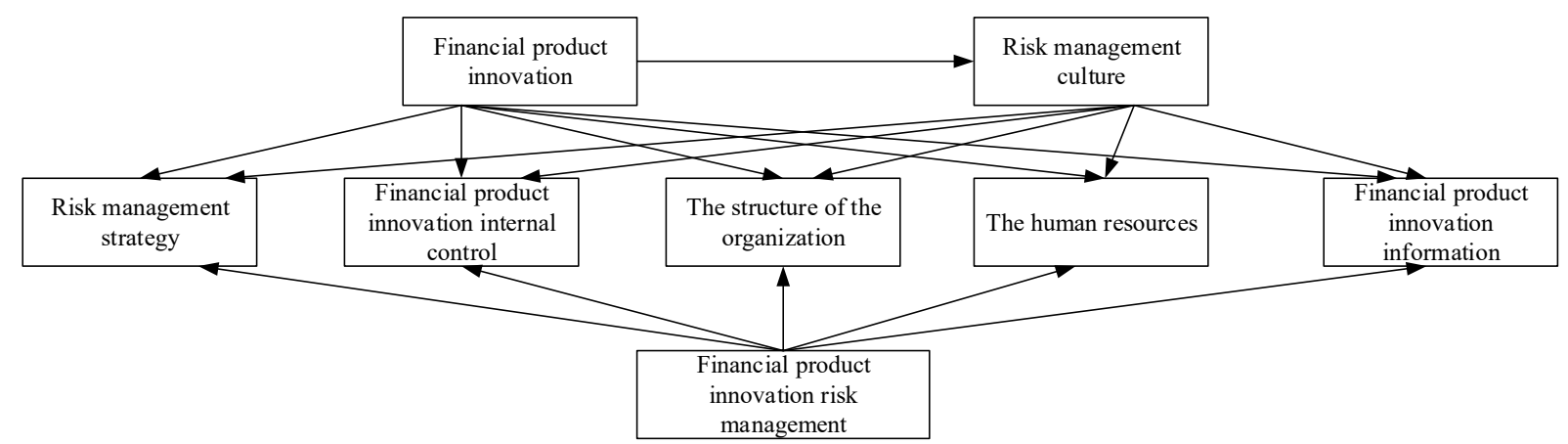

Figure 1. Commercial bank financial product innovation risk management theory model

On the assumption that the two commercial banks are developing some kind of financial products at the same time, the anti-demand function of the two commercial banks is $p=a-b\left(q_{1}+q_{2}\right)$, in which $\mathrm{p}$ represents the price, and $q_{1}$ and $q_{2}$ represent the output of the innovative products of the two commercial banks, respectively [7]. And $a$ and $b$ are the positive parameters of the inverse demand function, namely $\mathrm{a}>0, \mathrm{~b}>0$. The cost function of each financial institution is linear, $c_{i}=\frac{C_{i}}{1+\beta_{i}} q_{i}$, in which $C_{i}>0$ represents the unit cost of the commercial bank enterprise $\mathrm{i}$ [8]. $\beta_{i} \geq 0$ indicates the influence of the spill-over effect on the commercial bank enterprise i [9]. It indicates the positive cost externality of the bank because of the existence of the other bank, that is, the cost of innovative products has been reduced due to the existence of the competitor.

$$
\pi_{i}\left(q_{1}, q_{2}\right)=q_{i}\left[a-b\left(q_{1}+q_{2}\right)\right]-\frac{C_{i}}{1+\beta_{i}} q_{i},(i=1,2)
$$

Supposing that they do not have all the information about the demand function and it is assumed that commercial bank enterprise 1 updates its strategy according to the estimate of marginal profit in each round of abandoning, if the marginal profit is positive, then the output of the enterprise will 
increase in the next round of game, and on the contrary, the output will be reduced. This is also called the "myopia" adjustment strategy. The marginal profit of the commercial bank enterprise 1 is:

$$
\frac{\partial \pi_{1}}{\partial q_{1}}=a-2 b q_{1}-b q_{2}-\frac{C_{1}}{1+\beta_{1}}
$$

Thus, the output of the commercial bank enterprise 1 in the $\mathrm{k}+1$ round game is given by the following equation:

$$
q_{1}(k+1)=q_{1}(k)+\alpha_{1} q_{1}(k)\left[a-2 b q_{1}(k)-b q_{2}(k)-\frac{C_{1}}{1+\beta_{1}}\right]
$$

In the above equations, $\alpha_{1}>0$ represents the speed of output adjustment of commercial bank enterprise 1, which reflects the reaction speed of the commercial banks to marginal profit signals.

\section{Results and Discussion}

\subsection{Unclear Strategy of Financial Product Innovation}

Although China's financial industry, especially commercial banks, is constantly introducing innovative products, there is still a lack of clear strategic thinking in general. When developing and implementing innovation plans, commercial banks often appear to have low compliance with the overall development strategy of banks. For example, the overall development strategy of some regional commercial banks is to gain advantage in certain specific fields, such as small and medium-sized enterprises, but the innovation strategy is often followed by a comprehensive follow-up strategy, and the four state-owned shareholding banks will carry out comprehensive business in the whole country. Regional banks, with limited resources, compete for market share with four state-owned shareholding banks, and the final result is that the market share of innovative products is too low to keep the balance of profit and loss and even cause serious losses. Even four big state-owned commercial banks, because these banks lack more clearly innovative product innovation strategy, compared with Citibank, HSBC and other old commercial banks, the depth and breadth of innovative products have a great gap.

\subsection{Poor External Environment of Financial Product Innovation}

The innovation of financial products needs a suitable financial environment and relatively loose financial management system. However, there are various obstacles to financial innovation in the financial control, the economic environment and the management mechanism of the financial industry itself. In the first place, China's financial control is still quite strict. Compared with the commercial banks in western developed countries, the commercial banks of China have many restrictions in the process of financial product innovation, such as interest rate control, exchange rate control, operation scope and capital market, which make the financial product innovation behaviour of the commercial bank encountered many constraints. Secondly, the business of commercial banks in China is more interfered by the government at all levels. Various policies and measures introduced by the government have brought many adverse effects on the steady operation of commercial banks and other commercial banks, which make the commercial banks lose the motive force of financial innovation. Finally, China's financial market order has not yet been fully established, and the financial system still has a large degree of industry monopoly. The four big state-owned commercial banks, because of their monopolistic market share, strong capital strength and obvious talent superiority, make them in an obvious favourable position and often lack innovation motivation compete with other commercial banks, which is not conducive to the promotion of the innovation of financial products in the whole financial system.

\subsection{Insufficient Information Disclosure of Financial Product Innovation}

China's frequent exposure of "zero negative earnings" financial innovation products and the legal disputes arising therefrom has attracted the attention of all sectors of society. One of the important reasons for this kind of problem is that the information disclosure of innovative financial products is inadequate, the design of some commercial banks' innovative product specifications is complex, the 
contract terminology is difficult to understand, the expected rate of return is complicated, the expression of the adverse situation is obscure and so on. As a result, it makes it difficult for investors to understand the contract terms and the whole risk situation, thus causing that the commercial bank faces potential risks in the face of legal risks.

\subsection{Low Level and Single Structure of Financial Product Innovation}

Firstly, there are few original innovations in China's financial institutions, especially commercial banks. There are many foreign products and lack of financial products with financial intellectual property rights. China's banking industry has always ignored the primary innovation, and the vast majority of innovative products are essentially transplanted and cloned from abroad. Secondly, the technological content of innovative products is seriously inadequate. Most of the innovative products introduced by most commercial banks in China are the improvement of traditional business, such as asset business, debt service and intermediate business, lack of debt tool innovation, complex derivative financial product innovation and combined financial tool innovation. Finally, China's commercial banks' innovative business accounts for a smaller share of the overall business and cannot produce scale economy effect. Because China's financial innovation product structure is single, it is difficult to give full play to its function and role to avoid financial risks.

\subsection{Inaccurate Positioning of Innovative Market for Financial Products}

The inaccurate market positioning of Chinese commercial banks sometimes appears. For example, some commercial banks bond and sell high quality loan assets, and the result is not to achieve their target of decentralizing credit risk, instead of losing a large amount of fee incomes. Some banks have applied for the qualification of QDII (Qualified Domestic Investor Identification). However, because of their lack of fund management teams with rich experience in international investment, some of their funds have been liquidated, resulting in heavy loss of customers and impaired bank reputation. In addition, there is no overall marketing of target customers. Although some commercial banks continue to launch innovative products, they do not provide comprehensive service to the target customer group, which leads to lower customer satisfaction and bank reputation.

\section{Conclusion}

This paper makes a systematic and empirical analysis of the risk management of financial product innovation in China's commercial banks. It has a certain innovation in the research content and research methods, and analyses the motivation of the innovation of financial products. Based on the related theory, a new repeated game model for innovation of financial products with spill-over effect under different competitive strategies and risk constraints is established. Thirdly, the Nash equilibrium point of the model is determined and the stability condition of the equilibrium point is discussed.

However, the depth and precision of theoretical research and empirical research still need to be further improved due to the subjective and objective reasons of the scope of research, the availability of data and the ability of research. Firstly, in the construction of a repeated game model of the limited rational commercial banks' financial product innovation, there is no consideration of the impact of the government supervision factors on the model. Secondly, although the influence factors of the financial product innovation risk management have certain representativeness, there are still some shortcomings. Thirdly, it lacks the dynamic regulation of the dynamic risk of the innovation of financial products. Fourthly, due to the lack of the support of historical data, the measurement and analysis of the financial product innovation risk of commercial banks has not been effectively carried out, which is the biggest regret of this article.

\section{Acknowledgements}

The authors acknowledge the National Natural Science Foundation of China (Grant: 111578109), the National Natural Science Foundation of China (Grant: 11111121005). 


\section{References}

[1]. Australia R B O. Functions and Objectives of the Payments System Board[J]. Renewable \& Sustainable Energy Reviews, 2016, 57, pp.1611-1636.

[2]. Lin E M H, Sun E W, Yu M T. Systemic risk, financial markets, and performance of financial institutions[J]. Annals of Operations Research, 2018, 262(2), pp. 579-603.

[3]. Levrel H, Scemama P, Vaissière A C. Should We Be Wary of Mitigation Banking? Evidence Regarding the Risks Associated with this Wetland Offset Arrangement in Florida[J]. Ecological Economics, 2017, 135, pp. 136-149.

[4]. Zanoni P, Khetarpal S A, Larach D B, et al. Rare variant in scavenger receptor BI raises HDL cholesterol and increases risk of coronary heart disease[J]. Science, 2016, 351(6278), pp. 1166-1171.

[5]. Choi Y, Ye X, Zhao L, et al. Optimizing enterprise risk management: a literature review and critical analysis of the work of Wu and Olson[J]. Annals of Operations Research, 2016, 237(1-2), pp. 281-300.

[6]. Li Y, Zhen X, Cai X. Trade credit insurance, capital constraint, and the behavior of manufacturers and banks[J]. Annals of Operations Research, 2016, 240(2), pp. 395-414.

[7]. Sarafbank S, Esmaillzadeh A, Faghihimani E, et al. Effects of Legume-Enriched Diet on Cardiometabolic Risk Factors among Individuals at Risk for Diabetes: A Crossover Study. [J]. Journal of the American College of Nutrition, 2016, 35(1), pp. 31-40.

[8]. Saha S, Chandra B. A Cross-Sectional Blood Study in India:From Donation Activities of Donors to Blood Bank Services[J]. Current Science, 2016, 110(9), pp. 1789.

[9]. Mocellin P, Vianello C, Maschio G. Hazard investigation of dry-ice bank induced risks related to rapid depressurization of CCS pipelines: Analysis of different numerical modelling approaches[J]. International Journal of Greenhouse Gas Control, 2016, 55, pp. 82-96. 